\section{Nanotechnology developments: opportunities for animal health and production}

\author{
Anju Manuja, Balvinder Kumar, \\ Raj Kumar Singh \\ National Research Centre on Equines, \\ India
}

\begin{abstract}
Nanotechnology has opened up new vistas for applications in molecular biology, biotechnology and almost all the disciplines of veterinary and animal sciences. Excellence in animal health and production can be achieved by translation of this newer technology to create effective services and products for animals. The ability to manufacture and manipulate matter on the nanoscale has offered opportunities for application in diverse areas of animal sciences. Nanosensors, nanovaccines, adjuvants, gene delivery and smart drug delivery methods have the potential to revolutionize animal health and production. There can be numerous applications of the nanomaterials for disease diagnosis, treatment, drug delivery, animal nutrition, animal breeding, reproduction, tissue engineering and value addition to animal products. This paper reviews the recent developments in nanotechnology research and opportunities for application in animal sciences.
\end{abstract}

\section{Introduction}

Nanotechnology has emerged at the forefront of research and technology development. The term nano is derived from the Greek word meaning little old man or dwarf and is usually combined with a noun to form words such as nanometer, nanorobot and nanotechnology. According to the US government's National Nanotechnology Initiative, nanotechnology is defined as: Research and technology development at the atomic, molecular and macromolecular levels at the scale of approximately 1-100 nanometer range, to provide a fundamental understanding of phenomena and materials at the nanoscale and to create and use structures, devices and systems that have novel properties and functions because of their small and/or intermediate size. ${ }^{1}$ The ability to manufacture and manipulate matter on the nanoscale has offered opportunities to interfere with biology in new ways and with unprecedented precision. Researchers are able to handle biological materials (DNA, RNA, proteins or cells) in minute quantities. Nanosensors, nanovac- cines, adjuvants, gene delivery and smart drug delivery methods have the potential to revolutionize animal health and production. There can be numerous applications of the technology for disease diagnosis, treatment, drug delivery, animal nutrition, animal breeding, reproduction, tissue engineering and value addition to animal products. Recently, there have been some concerns about the potential toxic effects of nanoparticles in both human and animals. Therefore, there is a need to address safety, and other social issues that are likely to arise from these applications. This paper reviews the recent developments in nanotechnology research and the opportunities for application in animal sciences.

\section{Opportunities for animal health}

Nanoparticles have been used for diverse applications in animal health. The nanodrug formulations have been used against intracellular organisms and for treatment of brain tumors due to their small size and ability to cross the blood-brain barrier. The nanomaterials being developed for medical applications are tested and validated on laboratory animals. Therefore, these drugs have potential for use in domestic animals against many diseases of economic importance. Current research and possible applications of emerging nanotechnologies in animal health are presented below.

\section{Disease diagnosis}

Timely diagnosis is the key to any disease control strategy. Conventional diagnostic tests can take from hours to days to provide results. These tests are labor intensive and sometimes involve pathogen amplification. Such bottlenecks can be overcome by developing highly specific, sensitive, rapid, and robust diagnostics, including the portable pen-side tests employing nanoparticles fabricated with specific antibodies, peptides, nucleic acids, etc. Nanotechnology holds the potential for very early detection with high precision even before symptoms of the disease appear.

Nanotechnology could help in the development and optimization of biochips for the diagnosis of diseases and genetic predispositions. These diagnostic chips can be used to analyze thousands of genes simultaneously. Biochips enable instantaneous analysis and manipulation of biological samples, such as blood, plasma, serum, tissue, semen, other body fluids, including secretions and excretions for identification of molecules specific for a disease. High-density nanoarrays have been created using dip pen nanolithography. ${ }^{2}$ DNA and protein microarrays have been used for drug-effi-
Correspondence: Anju Manuja, Senior Scientist National Research Centre on Equines, Sirsa road, Hisar-125001, Haryana, India.

Tel. +91.1662.276748 - Fax: +91.1662.276217.

E-mail:amanuja@rediffmail.com

Key words: nanotechnology, nanodiagnostics, drug delivery, nanovaccines.

Contributions: the authors contributed equally.

Conflict of interests: the authors report no conflicts of interest.

Received for publication: 21 August 2011. Revision received: 21 January 2012.

Accepted for publication: 23 January 2012.

This work is licensed under a Creative Commons Attribution NonCommercial 3.0 License (CC BYNC 3.0).

(C) Copyright A. Manuja et al., 2012

Licensee PAGEPress, Italy

Nanotechnology Development 2012; 2:e4

doi:10.4081/nd.2012.e4

ciency tests, gene expression studies and identification of biomarkers for disease diagnosis. Bio barcodes have been developed for protein detection and used to detect prostate-specific antigen (PSA). ${ }^{3}$ PSA is routinely used as a marker for prostate cancer in humans. Using the polymerase chain reaction on the oligonucleotide, barcodes allow PSA to be detected at 3 attomolar concentration, which is about a million times more sensitive than comparable clinically accepted conventional assays. ${ }^{3}$ DNA detection in nanoliter sized samples is possible using a device with integrated fluidic channels, heaters, temperature sensors and fluorescence detectors. Lab-on-a-chip (LOC) offers the advantages of integrating sample handling and preparation, mixing, separation, lysing of cells and detection. ${ }^{4-6}$

Nanotechnology has also been found to be useful in improving latest non-invasive imaging techniques. Nanoparticles of perfluorocarbon have been used in ultrasonography and magnetic resonance imaging (MRI) for detection of fibrin and thrombus. ${ }^{7}$ The use of paramagnetic iron oxide nanoparticles as contrast agents in MRI enables identification of specific organs and tissues more efficiently. ${ }^{8}$ Fullerenes (or buckyballs) which are pure carbon molecules composed of at least 60 atoms of carbon have a promising future in the area of diagnostic imaging. Buckyballs containing radioactive agents can travel through the bloodstream and can be excreted as such, thus reducing the risk of radiation toxicity. ${ }^{9}$ Dendrimers are synthetic, 3-dimensional macromolecules having unique electronic, optical, optoelectronic, magnetic, chemical and 
biological properties. Dendrimers have also been used as contrast agents for imaging. ${ }^{10}$

Quantum dot nanocrystals can be excited to emit fluorescence with white light and can be linked to biomolecules to form long-lived sensitive probes. The ability to simultaneously tag multiple biomolecules could allow scientists to observe the complex cellular changes and events associated with disease. Quantum dots could offer a cheap and easy way to screen a blood sample for the presence of a number of protein biomarkers and different viruses at the same time. ${ }^{11}$ Another approach in nano-based diagnostics consists in delivering superparamagnetic nanoparticles in the bloodstream to target diseased receptor cells. These nanoparticles are made from iron oxides that enhance the ability of the nanoparticles to locate diseased cells under a magnetic field. ${ }^{12}$ Nanoshells are also useful for diagnostic purposes in whole blood immunoassays. These are concentric sphere nanoparticles consisting of a dielectric (typically gold sulfide or silica) core and a metal (gold) shell. These particles are considered a very special kind of nanoparticle because they combine infrared optical activity with the unique biocompatibility of gold colloid. Gold nanoshells can be conjugated to antibodies and the size can be modulated so that they respond to near infrared wavelength, which has the ability to penetrate whole blood specimens. With this method it is possible to detect immunoglobulins at a concentration range of nanograms per milliliter in plasma and whole blood. ${ }^{13}$

Nanosized, multipurpose sensors are being developed to detect almost everything from physiological parameters to toxic compounds. Carbon nanotubes are being investigated as biosensors to detect glucose, ethanol, hydrogen peroxide, immunoglobulins, and as an electrochemical DNA hybridization biosensor. ${ }^{12}$ Magnetic microparticle probes coated with target protein binding antibodies and a unique DNA sequence have been used as an ultrasensitive method for detecting protein analytes, such as prostate-specific antigen (PSA). ${ }^{3}$ A rapid, sensitive test has been developed for detection of FMD virus which relies on the sensitivity and movement of liquid crystals at the nanoscale in the presence of a target molecule. Virus binding in a detection region is identified by changes in liquid crystal orientation. $^{14}$

\section{Drug delivery}

The effective delivery of therapeutic molecules has been a major barrier to obtain targeted response against the disease agent. Many drugs are effective in treating diseases but most of them also have certain impeding factors, like toxicity and cell impermeability. The drug of interest can be dissolved, entrapped, adsorbed, attached or encapsulated into the nanoparticle matrix to achieve more precise drug targeting, minimize drug degradation, prevent harmful side effects, and increase the availability of the drug at the required site. Some of the materials used as nanocarriers for drug delivery are listed in Table 1. Functional drug carriers are nanostructures which can be controlled by linkage to a drug, a targeting molecule, and/or an imaging agent.

Nanomaterial encapsulation could improve diffusion and degradation and allow a time controlled release of a drug through pores or by diffusion of the drug during capsule degradation. Furthermore, nanomaterials could serve as camouflage to avoid immune responses or as agents which could catalyze or respond to certain molecules or chemical events. These systems have an impact on the rate of absorption, distribution, metabolism, and excretion of drugs or other substances in the body. They allow the drug to bind to its target receptor and influence the receptor's action. Some examples in the literature include use of copolymer PLGA (D, L-lactide-co-glycolide) in the form of nanocapsules to deliver porcine somatotropin (pST) in a time-controlled fashion to swine. ${ }^{15}$ Supplying encapsulated cells to the body could also be a valuable way to treat enzyme or hormone deficiency diseases. Nanopores, tiny cell-containing chambers within crystalline silicon wafers which allow passage of small molecules but impede the passage of larger molecules are being developed.16 Rat pancreatic cells encapsulated in these chambers remain viable for weeks, and secrete insulin through the pores, and at the same time the cells remain protected from the immune responses. ${ }^{17}$ The flow of materials through nanopores can also be externally regulated to achieve precise control of ion transport.

Researchers hope to functionalize a buckyball by binding it to molecules that react to changes in $\mathrm{pH}$. This means that the bound drug would only be released at the infected area. ${ }^{18}$ Fullerene-decorated chemotherapeutic constructs, fullerene-radiopharmaceuticals and fullerene-based liposome systems for the delivery of single or multiple drug loads are under development. ${ }^{19}$

A nanoemulsion is obtained by the milling of a drug to nanometer particle size and suspension in appropriate solvents to improve

Table 1. Some of the proteins, polysaccharides synthetic polymers and lipids used as nanocarrier for drug delivery.

\begin{tabular}{|c|c|c|c|}
\hline Proteins & Polysaccharides & Synthetic polymers & Lipids \\
\hline Gelatin & Alginate & Poly ( $\varepsilon$-caprolactone), (PECL), and & Liposomes \\
\hline Albumin & Dextran & Poly (lactic acid) (PLA) & Lipid nanocapsules \\
\hline Lectins & Chitosan & Poly (lactide-co-glycolide) (PLGA) & $\begin{array}{c}\text { Solid lipid } \\
\text { nanoparticles }\end{array}$ \\
\hline Legumin & Agarose & Polystyrene & \\
\hline Vicilin & Pullulan & & \\
\hline
\end{tabular}

drug metabolism and pharmacokinetic properties. One very important characteristic of nanoemulsions is that they do not affect cell structures of higher organisms, making them ideal for use in animals and humans. Nanoemulsions are completely safe when applied externally, but the oil droplets can also destroy erythrocytes and sperm cells. ${ }^{9}$ In the near future, we may see bactericidal and viricidal products that can be used topically in animals and humans.

The nanoformulations have been successfully used for drug delivery against fungal, protozoan and bacterial diseases like candidiasis, leishmaniasis, salmonellosis, brucellosis and tuberculosis in animal models of the diseases (Table 2). The development of lipid-based preparation of amphotericin B agents such as abelcet and and liposomal preparation of amphotericin B agents (AmBisome) have shown broad spectrum activity of amphotericin B while reducing adverse events. ${ }^{31}$ These nanoformulations have been found to be superior in terms of efficacy and safety than their conventional counterparts. Smart drug delivery systems are being envisioned that will have the capability to detect and treat an infection, nutrient deficiency, or other health problems even before symptoms are evident. A molecular-coded address label attached to drug-loaded nanocarriers could allow targeted delivery of also be programmed for chemical detection and decision-making capability for self-regulation and delivery of drug or nutrient as needed. Smart delivery systems are also able to monitor the effects of the delivery of pharmaceuticals, nutraceuticals, nutrients, food supplements, bioactive compounds, probiotics, chemicals and vaccines. ${ }^{12}$ Nanoshells, superparamagnetic nanoparticles and quantum dots have also been designed to locate, bind to and kill diseased cells. ${ }^{32}$ Nucleic acid engineering-based probes and barcoding methods offer powerful new ways to deliver treatment or to prevent a particular disease.

\section{Therapeutics}

Smart drugs have been designed which become medically active only in specific circumstances, such as release of antibiotic only in the presence of an infection. ${ }^{33}$ For example, the drugs. These smart delivery systems could 
the common antibiotic molecule gentamicin was bound to a hydrogel using a peptide linker which can only be cleaved by a protease enzyme formed by Pseudomonas aeruginosa; thus, the antibiotic is not released in absence of the organism.33 Proteases specific to particular bacteria can be used as the signal for the release of different spectra of antibiotics from the same matrix depending on the strain of bacterium. Similarly, an alternative antibiotic release system triggered by thrombin activity, which accompanies Staphylococcus aureus wound infections, has been successfully tested as a high-specificity stimulus-responsive controlled drug release system. ${ }^{34}$ Other stimulusresponsive hydrogels are currently being studied, including a hydrogel composite membrane co-loaded with insulin and glucose oxidase enzyme that exhibits a 2-fold increase in insulin release rate when immersed in glucose solution, demonstrating chemically stimulated controlled release. ${ }^{35,36}$ Glycodendrimers have been fabricated that mimic the components of outer surfaces of mammalian cells. The virus particles bind to outer branches of these dendrimers instead of the natural cells and are deactivated. Such glycodendrimers have also been used to trap and deactivate some strains of influenza virus particles. ${ }^{37}$ There are ongoing attempts to build micro-electromechanical system (MEMS)-based microrobots intended for in vivo use. Cytobots and karyobots for performing wireless intracellular surgery, artificial mechanical red blood cells or respirocytes, and white cells called microbivores are all under development. ${ }^{13}$ Nanoshells embedded in a drug-containing hydrogel polymer are being used for targeted delivery of drug molecules. When heated with an infrared laser, the nanoshells selectively absorb the infrared frequencies, melt the polymer coating, and release their drug at a specific site. ${ }^{38}$

\section{Drug discovery}

Drug research and discovery has greatly improved through the application of micro and nanofluidic arrays and lab-on-a-chip devices. The disciplines of biology, pharmaceutics, engineering and microelectronics are fusing and moving to the nanoscale to provide systems which can identify a disease and provide a therapeutic solution. These devices will allow researchers to perform a sequence of experiments on a single chip, thus greatly reducing the costs involved in drug discovery.

Understanding an individual's genetic makeup is thought to be the way to create personalized drugs with greater efficacy and safety. Single nucleotide polymorphisms (SNPs) can be used to determine different susceptibilities to drugs between individuals. ${ }^{39}$ High-density chip technology has been used to create microarrays for comparison with clinical sam-

Table 2. Nanoformulations against infectious organisms tested for drug delivery in experimental animals with potential for veterinary use.

\begin{tabular}{|c|c|c|c|c|c|}
\hline Disease & Drug & Nanoparticles & Animal used & Effect & Reference \\
\hline \multirow[t]{3}{*}{ Systemic Candidiasis } & Amphotericin B & $\begin{array}{c}\text { Poly (epsilon-caprolactone) } \\
\text { nanospheres coated with } \\
\text { poloxamer } 188 \text { (AmB-NP) }\end{array}$ & Mice & Antifungal activity & 20 \\
\hline & & $\begin{array}{l}\text { Mixed micelles with the same } \\
\text { surfactant(AmB-MM) }\end{array}$ & & & \\
\hline & Amphotericin B & $\begin{array}{c}\text { Pegylated amphotericin B } \\
\text { (AmB) liposomes (PEG-AmB-LIP) }\end{array}$ & Mice & Antifungal activity & 21 \\
\hline \multirow[t]{3}{*}{ Leishmaniasis } & Amphotericin B & PLGA nanoparticles & Mice & Antileishmanial activity & 22 \\
\hline & Primaquine & Poly (hexyl cyanoacrylate) & Mice & $\begin{array}{l}20 \text {-fold increased } \\
\text { activity as compared to the } \\
\text { free drug against } \\
\text { intracellular } L \text {. donovani }\end{array}$ & 23 \\
\hline & Arjunglucoside & $\begin{array}{l}\text { Nanogels (cross-linked } \\
\text { random co-polymer of } \\
\text { N-isopropylacrylamide } \\
\text { (NIPAAM) and N-vinyl pyrrolidone } \\
\text { ad Poly-dl-lactide (PLA) nanoparticles }\end{array}$ & Hamsters & $\begin{array}{l}\text { Nanoformulations showed } \\
\text { anti-leishmanial activity and } \\
\text { were more effective in } \\
\text { lowering the spleen parasite } \\
\text { load as compared to free drug. } \\
\text { The preparations were non- } \\
\text { hepatotoxic and non-nephrotoxic. }\end{array}$ & 24 \\
\hline Salmonellosis & Ampicillin & Poly(isobutyl cyanoacrylat) & Mice & $\begin{array}{l}120 \text {-fold increase in the } \\
\text { efficacy of the antibiotic }\end{array}$ & 25,26 \\
\hline Brucellosis & Streptomycin and doxycycline & $\begin{array}{c}\text { Block copolymers of poly } \\
\text { (ethylene oxide- } \beta \text {-sodium } \\
\text { acrylate) (PEO- } \beta \text {-PAA_1Na) } \\
\text { and poly (sodium acrylate) } \\
\text { (PAA_INa) }\end{array}$ & Mice & $\begin{array}{l}\text { Improvement in performance } \\
\text { as compared to the free drugs. } \\
\text { Two doses of the nanoplexes } \\
\text { significantly reduced the Brucella } \\
\text { melitensis load in the spleen } \\
\text { and liver. }\end{array}$ & 27 \\
\hline \multirow[t]{2}{*}{ Tuberculosis } & $\begin{array}{l}\text { Rifampin (RMP), isoniazid } \\
\text { (INH), and pyrazinamide (PZA) }\end{array}$ & $\begin{array}{c}\text { Coencapsulated in PLGA } \\
\text { nanoparticles }\end{array}$ & Mice & $\begin{array}{l}\text { Complete bacterial clearance } \\
\text { from the organs. }\end{array}$ & 28 \\
\hline & $\begin{array}{l}\text { Rifampin (RMP), isoniazid } \\
\text { (INH), and pyrazinamide (PZA) }\end{array}$ & $\begin{array}{l}\text { Co-encapsulated in wheat } \\
\text { germ agglutinin-functionalized } \\
\text { PLGA nanoparticles }\end{array}$ & Guinea pigs & $\begin{array}{l}\text { Three doses administered } \\
\text { fortnightly for } 45 \text { days produced } \\
\text { a sterilizing effect in lung } \\
\text { and spleen. }\end{array}$ & 29 \\
\hline $\begin{array}{l}\text { Chagas disease } \\
\text { (Trypanosoma cruzi) }\end{array}$ & Etanidazole (ETZ) & Liposomes & Mice & $\begin{array}{l}\text { Endovenous administration of } \\
\text { L-ETZ at } 14 \mu \mathrm{g} / \text { mouse dose } \\
\text { provoked significant decrease } \\
\text { in parasitemia. }\end{array}$ & 30 \\
\hline
\end{tabular}


ples to identify disease or drug response related SNPs. Polymorphisms in genes that code for these enzymes can influence their ability to metabolize certain drugs. ${ }^{40}$

The discovery of new drugs requires knowledge of the disease mechanism and identification of a target. Most drug targets are proteins that are either defective or abnormally expressed, or present within a pathogen. The site of interaction of the drug with the target is often at the protein's active site. Nanotechnology can enhance the drug discovery process through miniaturization, automation, speed and reliability of assays. DNA microarray technology is successfully used for identification of drug targets, identification of small molecule drug candidates, and for toxicogenomic studies. ${ }^{41}$ The necessity of high density arrays for drug discovery has become increasingly apparent as the number of potential targets to be investigated has increased as a result of genome sequencing efforts. Highthroughput (HT) array analysis provides a method of identifying drug targets and pathways for complex disease mechanisms. Once a disease pathway is identified, it needs to be validated and then verified by disrupting this pathway. Using whole-genome expression profiling, a wide range of effects that result from disrupting the pathway can be understood so that potential drug targets for drug design can be evaluated. After identifying and validating a target, HT arrays can also be used to screen libraries of compounds to identify those that disrupt expression of particular disease genes. Protein biochips can make direct measurements of the relative levels of proteins and their interactions with other molecules. This makes them ideal for use in searching for relevant targets and disease-specific marker proteins. The technique allows scientists to monitor cell metabolism and its response to external stimuli. Protein microarrays can be regarded as tools which will enable rapid progress in the study of proteomics. Bioinformatics has been used to predict the 3D structures of targets and potential chemicals that could interact with them and inhibit protein function, by comparing primary amino acid sequences of novel proteins with the determined 3D structure of known proteins.

\section{Nanovaccines and vaccine adjuvants}

The increase in the incidence of diseases, in spite of mass immunization, and the lack of efficient vaccines in many cases indicates the need to create new and effective vaccines based on new technologies. The vaccines being used in the present scenario have limitations especially in maintaining the cold chain till delivery to the animal. Other limitations are due to the limited life span of the vaccine. Therefore, durability of the vaccines at room temperature may provide a solution to this problem. Nanotechnology may exploit the structures of the microorganisms which have protective properties. For example, spores of Bacillus subtilis have been used to display heterologous antigens which have advantages over conventional vaccines in terms of storage in lyophilized forms, ease of production and safety. ${ }^{42}$ Spore-based nanovaccines against tetanus with heterologous antigens have been used successfully in humans. ${ }^{43}$ The same technology can be applied for the production of stable and safe vaccines against many diseases in animals. Nanoparticles such as latex, polystyrene, gold and silica covalently linked to antigen have been used to evoke cell-mediated immune responses (CMIRs) as well as antibodies with minimal side-effects. ${ }^{44}$ Particles of degradable and non-degradable biocompatible materials such as chitosan, gold, silica or polystyrene, have been used as efficient antigen carriers and some have been shown to have an adjuvant effect. ${ }^{45,46}$ Synthetic virus-like particles (VLPs), empty capsid particles and corelike particles (CLPs) which contain immunodominant regions to provide protection against many diseases at a time with singledose vaccination can be designed and developed with nanotechnology approaches. ${ }^{47-49}$

Researchers are also developing adjuvants formulated with nanobeads of polystyrene conjugated to ovalbumin to increase vaccine efficacy without the inflammatory responses. In sheep, antigen covalently linked to inert nanobeads with a size range of 40-50 nm has been used to induce antibodies and CMIRs. ${ }^{50}$ Hydrophobic membrane-associated viral antigens have been incorporated in $40 \mathrm{~nm}$ particles of immunestimulatory complexes (ISCOMs), as for initiating an immune response in veterinary vaccines against many viral diseases. A vaccine against gonadotrophin-releasing factor using ISCOMbased adjuvant has been used as an anticonception vaccine for horses. ${ }^{51}$ Conventional vaccines are usually multi-injection and multidose delivery systems. Needle-free routes, such as the intranasal or the oral route, or patches of microprojections to the skin, are for the moment in the experimental stages of development but may have a great future ahead in nanovaccination. ${ }^{50}$ Encapsulation of antigens into bioactive nanoparticles is a promising approach to nasal vaccine delivery. ${ }^{52}$ Nanoemulsion, a water-in-oil formulation stabilized by small amounts of surfactant, has been found to be non-toxic to mucous membranes and biocidal against many enveloped viruses, and has been used in influenza virus vaccine. ${ }^{53}$ The development of polymer-based nanoparticles is useful in the delivery of oral DNA vaccines. ${ }^{54}$ Nano-encapsulated vaccine tablets formulated for oral vaccine delivery against Newcastle disease in poultry provided protective antibody response..$^{55}$ Vaccine delivery in the form of tablets may overcome the need of a cold chain during transportation of vaccines. Some of the nanovaccines against infectious organisms tested in experimental animals with potential for veterinary use are listed in Table 3.

\section{Gene therapy or DNA delivery}

A critical barrier to successful gene therapy remains the formulation of an efficient and safe delivery vehicle. The development of new carrier systems for gene delivery represents an enabling technology for treating many genetic disorders and genetic manipulation in livestock. Non-viral delivery systems have been increasingly proposed as alternatives to viral vectors owing to their safety, stability and ability to be produced in large quantities. ${ }^{74}$ Nanoparticles have been used as gene delivery vectors for gene therapy. In vitro and in vivo gene delivery systems based on the various nanoparticulate approaches using cationic lipids, cationic polymers, gold nanoparticles, magnetic nanoparticles, quantum dots, silica nanoparticles, fullerenes, carbon nanotubes and supramolecular systems have been reported. ${ }^{75}$ Some approaches employ DNA complexes containing lipid, protein, peptide or polymeric carriers, as well as ligands capable of targeting DNA complexes to cell-surface receptors on the target cells and ligands for directing the intracellular traffic of DNA to the nucleus. Promising results were reported in the formation of complexes between chitosan and DNA. ${ }^{76}$ Although chitosan increases transformation efficiency, the addition of appropriate ligands to the DNA-chitosan complex seems to achieve a more efficient gene delivery via receptor-mediated endocytosis. ${ }^{77}$ The results suggest that chitosan has comparable efficacy without the associated toxicity of other synthetic vectors and can, therefore, be an effective gene-delivery vehicle in vivo. Fullerenes have also been used as a carrier for gene delivery. Arrays of vertically aligned carbon nanofibers (VACNFs) have been described for DNA delivery by pressing the cells onto the DNA-coated VACNFs which then penetrate the cells and introduce the DNA. ${ }^{78}$ Silica nanoparticles are also being investigated for the delivery of DNA into mammalian cells. ${ }^{79}$ Dense silica nanoparticles enhance the uptake of DNA by cells at their surface and increase the efficiency of DNA delivery.

A hybrid nanodevice, composed of nanocrystals of biocompatible titanium dioxide $\left(\mathrm{TiO}_{2}\right)$ semiconductor covalently attached with snippets of oligonucleotide DNA, has been created. ${ }^{13,80}$ These nanocomposites not only retain the intrinsic photocatalytic capacity of $\mathrm{TiO}_{2}$ and the bioactivity of the oligonucleotide DNA, but they also possess the unique property of a 
light-inducible nucleic acid endonuclease. This simple nanocrystal nanodevice might be used to target defective genes that play a role in single gene defects, genetic diseases and neurological disorders.

Multisegment gold/nickel nanorods are being explored as tissue-targeted carriers for gene delivery into cells. The nanorods are functionalized by attaching DNA plasmids to the nickel segments and transferrin, a cell-targeting protein, to the gold segments, using molecular linkages that selectively bind to only one metal and thus impart biofunctionality to the nanorods in a spatially defined manner. Extra segments could be added to the nanorods, such as an endosomolytic agent, or magnetic segments to allow manipulating the nanorods with an external magnetic field. ${ }^{81}$
Starburst dendrimers are tree-shaped synthetic molecules with a regular branching structure emanating outward from a core. The peripheral layer can be made to form a dense field of molecular groups that serve as hooks for attaching other useful molecules, such as DNA, which can enter cells while avoiding triggering an immune response. ${ }^{13}$ Upon encountering a living cell, dendrimers of a certain size

Table 3. Nanovaccines/adjuvants against infectious organisms tested in experimental animals with potential for veterinary use.

\begin{tabular}{|c|c|c|c|c|c|}
\hline Organism/agent & Polymer & Route & Specie & Immune response & Reference \\
\hline $\begin{array}{l}\text { Recombinant } \\
\text { Bacillus anthracis } \\
\text { protective antigen (rPA) }\end{array}$ & Water-in-oil nanoemulsion & Intranasal & Mice and guinea pigs & $\begin{array}{l}\text { Serum and bronchial } \\
\text { IgG antibodies after } \\
\text { either one or two mucosal } \\
\text { administrations }\end{array}$ & 56 \\
\hline Influenza Virus & $\begin{array}{l}\text { Soybean oil-in-water } \\
\text { nanoemulsion }\end{array}$ & Intranasal & Ferrets & $\begin{array}{l}\text { Mucosal and serum antibody } \\
\text { responses as well as a robust } \\
\text { cellular } \mathrm{T}_{\mathrm{H}} 1 \text { immune response }\end{array}$ & 57 \\
\hline $\begin{array}{l}\text { Recombinant } \\
\text { Leishmania } \\
\text { superoxide } \\
\text { dismutase }\end{array}$ & Chitosan & Subcutaneous & Mice & $\begin{array}{l}\text { Increased immunogenicity toward } \\
\text { cell-mediated immunity ( } \mathrm{T}_{\mathrm{H}} 1 \text { cells } \\
\text { producing IgG2a in mice) that is } \\
\text { effective in Leishmania eradication }\end{array}$ & 58 \\
\hline $\begin{array}{l}\text { Influenza virus } \\
\text { hemagglutinin }\end{array}$ & Poly(gamma-glutamic acid) & Intranasal & Mice & $\begin{array}{l}\text { Induced cell-mediated immune } \\
\text { responses and neutralizing } \\
\text { antibody production }\end{array}$ & 59 \\
\hline $\begin{array}{l}\text { Helicobacter pylori } \\
\text { lysates }\end{array}$ & PLGA nanoparticles & Oral & Mice & $\begin{array}{l}\text { Mucosal IgA response as well } \\
\text { as serum IgG1 and IgG2b }\end{array}$ & 60 \\
\hline Tetanus toxoid & $\begin{array}{l}\text { Sulfobutylated pol } \\
\text { (vinylalcohol)-graft- } \\
\text { PLGA nanoparticles }\end{array}$ & Oral/Nasal & Mice & Higher IgG and IgA titers & 61 \\
\hline Tetanus toxoid & PLA-PEG nanoparticles & Nasal & Mice & Increased IgG and IgA levels & 62 \\
\hline Bordetella pertussis & PLGA nanoparticles & Oral & Mice & IgA and IgG & 63 \\
\hline Salmonella enteritidis & Poly(anhydride) nanoparticles & Oral & Mice & $\begin{array}{l}\text { Provided } 80 \% \text { protection whereas } \\
\text { only } 20 \% \text { protection by control } \\
\text { formulation }\end{array}$ & 64 \\
\hline $\begin{array}{l}\text { Rotavirus DNA } \\
\text { encoding for outer } \\
\text { capsid proteins }\end{array}$ & PLGA nanoparticles & Oral & Mice & $\begin{array}{c}\text { Serum IgG, IgM, and IgA as well as } \\
\text { intestinal IgA }\end{array}$ & 65 \\
\hline $\begin{array}{l}\text { Bovine parainfluenza } \\
\text { type } 3 \text { virus }\end{array}$ & $\begin{array}{c}\text { PLGA nanoparticles } \\
\text { poly(methyl methacrylate }\end{array}$ & Nasal & Mice & $\begin{array}{l}\text { Higher levels of specific antibody than } \\
\text { mice immunized with the viral } \\
\text { proteins alone }\end{array}$ & 66 \\
\hline Streptococcus equi & $\begin{array}{l}\text { PCL nanoparticles, } \\
\text { chitosan, alginate }\end{array}$ & Nasal & Mice & High immunogenicity & 67 \\
\hline $\begin{array}{l}\text { Pneumococcal surface } \\
\text { antigen A }\end{array}$ & Chitosan-DNA nanoparticles & Nasal & $(\gamma-\mathrm{II}$ & $\begin{array}{l}\text { Increased serum IgG and IgA in mucosal } \\
\text { lavages, enhanced gamma interferon } \\
\text { FN) and IL-17A levels in splenic lymphocytes }\end{array}$ & 68 \\
\hline $\begin{array}{l}\text { M. tuberculosis } \\
\text { protective epitopes }\end{array}$ & Chitosan nanoparticles & Pulmonary & Mice & Increase in levels of $\gamma$-IFN & 69 \\
\hline $\begin{array}{l}\text { Foot-and-mouth } \\
\text { disease virus peptide }\end{array}$ & Gold nanoparticles & Parentral & Mice & $\begin{array}{l}\text { Three-fold increase in the antibody } \\
\text { response compared to the response } \\
\text { to original peptide }\end{array}$ & 70 \\
\hline $\begin{array}{l}\text { Foot-and-mouth } \\
\text { disease virus peptide }\end{array}$ & Nanobeads & Parentral & Sheep & $\begin{array}{l}\text { Enhanced cell-mediated (CM) and } \\
\text { humoral immune responses }\end{array}$ & 71 \\
\hline $\begin{array}{l}\text { Herpes simplex } \\
\text { virus-2 proteins } \\
\text { (HSV-2) }\end{array}$ & $\begin{array}{l}\text { Calcium phosphate } \\
\text { (CP) nanoparticles }\end{array}$ & $\begin{array}{l}\text { Intravaginal } \\
\text { Intranasal }\end{array}$ & Mice & $\begin{array}{l}\text { High levels of specific mucosal IgA } \\
\text { and IgG in vaginal lavage fluids } \\
\text { higher survival rate and less } \\
\text { clinical infection }\end{array}$ & 72 \\
\hline Influenza vaccine & NanopatchTM & Skin patch & Mice & $\begin{array}{l}\text { IgG responses with more } \\
\text { than } 100 \text {-fold less antigen as } \\
\text { compared to conventional }\end{array}$ & 73 \\
\hline
\end{tabular}


trigger a process called endocytosis to enter the cell. Once inside, the DNA is released and migrates to the nucleus where it becomes part of the cell's genome. The technique has been tested on a variety of mammalian cell types and in animal models. Radio-frequency antennas, 1.4 nanometer gold nanocrystals of less than 100 atoms have been developed to control gene expression through remote electronic switching. ${ }^{2}$ This requires attaching gold nanoparticles to specific oligonucleotides which, when added to a sample of DNA, would bind to complementary gene sequences, blocking the activity of those genes and effectively turning them off. Applying the radio frequency magnetic field then heats the gold particles, causing their attached DNA fragments to detach, turning the genes back on. The longterm goal is to apply the antennas to living systems and control DNA (e.g. gene expression, the ability to turn genes on or off) via remote electronic switching. ${ }^{13}$

\section{Tissue repair}

Efforts are centered on using nanomaterials to repair and replace damaged or diseased tissues. Nanomaterial coatings could increase the adhesion, durability and lifespan of implants. Nanostructure scaffolds could provide a framework for improved tissue regeneration. Moreover, nanomaterial implants could be engineered for biocompatibility with the host environment to minimize side effects and the risk of rejection. In the longer term, the development of nanoelectronic systems that can detect and process information could lead to nanodevices that serve as retina implants by acting as photoreceptors and cochlear implants by improving nerve stimulation. ${ }^{19}$ The involvement of microelectronics or nanotechnology in creating an artificial tissue or organ as a replacement for those terminally diseased has been envisaged. Similar approaches can also be used successfully in animals for tissue repair/replacement. It might be possible to reinforce bone matrices with nanoparticles just like carbon fibre, making it feasible to repair animal bone. Nanoengineering of hydroxyapatite for bone replacement has been described in the literature..$^{83,84}$

\section{Opportunities for animal production}

The potential applications of the nanotechnology in animal breeding and reproduction, animal nutrition and value addition to animal products are discussed as under

\section{Animal breeding and reproduction}

Reproduction management is an important part of the sustainable production of livestock. Detection of estrus is a major problem in reproductive management of farm animals. Nanotubes are being synthesized as implantable devices under the animal skin for detection of estrus. ${ }^{85}$ Changes in estradiol levels in animal blood can be determined to provide real-time measurement of blood estradiol. The signal from this sensor will be incorporated as a part of a central monitoring and control system to actuate breeding. The natural follow up would be to have an implanted nanocapsule of semen triggered on demand to fertilize an egg. Microfluidic biochips are being used to segregate male sperm from female eggs for sex selection for animal breeding. ${ }^{86}$ Microfluidic devices can not only sort sperm and eggs, but also bring them together in a way that mimics the movement of natural reproduction. This technique would make mass production of embryos cheap, quick and reliable. Probes of commercially valuable traits such as disease resistance, athletic ability and leanness of meat on biochips will be able to speedily identify champion breeders and screen out genetic diseases.

\section{Animal nutrition}

Due to poor storage conditions of animal feeds, many fungi easily grow and produce toxins causing mycotoxicosis. The Food and Agriculture Organization (FAO) of the United Nations has estimated contamination of $25 \%$ of cereals with mycotoxins each year. ${ }^{87}$ The economic effects of this contamination on the agriculture sector is enormous, because it results in a reduced nutritional value of food and feedstuff, a decrease in meat production from animals, and toxicity in users of dairy products. A nanocomposite of $\mathrm{MgO}-\mathrm{SiO}_{2}$ has been used as an effective adsorbing agent for removal of aflatoxin from wheat flour. ${ }^{88}$ Similarly, a modified montmorillonite nanocomposite (MMN) has been used to reduce the toxicity due to aflatoxin in feeds of broiler chicks..$^{89}$

Nanoparticles have been used to enhance detection of a variety of chemical and microbial contaminants in feed. Poultry is a key source of Campylobacter infection in humans and its prevalence on carcasses is very high. ${ }^{90}$ Researchers have hypothesized about reducing Campylobacter in vivo using polymeric nanoparticles fed to turkey. ${ }^{91}$ Nanoparticles consisting of a polystyrene (PS) base, polyethylene glycol (PEG) linker, and a mannose targeting-biomolecule that adheres to $E$. coli have been developed. ${ }^{92}$ The particles bind the pathogens in the gut of livestock to prevent colonization and growth, and are removed in the waste. The nanoparticles could replace traditional sub-therapeutic uses of antibiotics and reduce the development of antibiotic-resistant bacteria. Silver nanoparticles have been used as an additive in diets for weanling pigs resulting in an increase in the growth. ${ }^{93} \mathrm{Cu}$ (II)exchanged montmorillonite nanoparticles (MMT-Cu) have been used to investigate the effect on growth performance, digestive function and mucosal disaccharase activities of weaned pigs. The potential effect has been reported to be mediated through antimicrobial properties of the nanoparticles. The addition of MMT-Cu to the diet increased the average daily weight gain, feed efficiency and digestibility as compared with those of the control and $\mathrm{CuSO}_{4}$ groups.$^{94}$ Nanosized minerals, vitamins or supplements developed for food application in human beings can also be used for animal feed. Nanosized additives have also been specifically developed for animal feed. Nanosized liquid vitamin mixes are available for use in poultry and livestock feed.

\section{Value addition to animal products}

Nanotechnologies offer a variety of benefits to the whole food chain from food processing, packaging, identification and tracking to quality control of animal products. Nanotechnology-based detection systems can be used for identification and tracking of animals and animal products. ${ }^{12,21}$ It is possible to provide information regarding origin of animal, environmental practices used in production, food safety and other records related to animal welfare issues to stakeholders and consumers.

Applications of nanotechnologies in food processing include the use of nanofood ingredients in the form of nano-structures for improved tastes and textures. Nanosized or nanoencapsulated food additives and supplements can improve dispersability of fat-soluble additives in food products, improve taste, enable hygienic food storage, reduce the use of fat, salt, sugar and preservatives, and improve the uptake and bioavailability of nutrients and supplements. Nanosized carrier systems for nutrients and supplements based on nanoencapsulated substances like liposomes, micelles or protein-based carriers are also used to mask the taste of certain ingredients and additives, or to protect them from degradation during processing. ${ }^{95}$ Nanomaterials being used in packaging include plastic-polymer composites with nanoclay for gas barrier, nano-silver and nano-zinc oxide for antimicrobial action, nano-titanium dioxide for UV protection, nano-titanium nitride for mechanical strength, and nano-silica for hydrophobic surface coating, etc.

Nanotechnology also has applications in improving quality by detecting and removing pathogens from the animal products. Nanoparticles are being used to remove Campylobacter and E. coli from poultry products. $^{90-92}$ Listeria monocytogenes, another foodborne pathogen was detected in spiked milk 
samples by magnetic nanoparticle-based immune-magnetic separation combined with real-time PCR. ${ }^{96}$ A fluorescent bio-barcoded DNA assay has been developed for the rapid detection of the Salmonella enteritidis, based on two nanoparticles. ${ }^{97}$ Nanosensors can detect very small amounts of a chemical contaminant, virus, or bacteria in food systems. A hand-held chip detects animal cytochrome b genes in food or feed products. It enables rapid multi-sampling and detects the presence of animal products from forty different species as a means to locate the source of pathogens. ${ }^{98}$ Gold nanoparticles (GNPs) have been used to detect contamination of melamine in raw milk samples by the naked eye and no sophisticated instruments are required. ${ }^{99}$ The method is promising for detection of melamine contamination in other foods, such as eggs and animal feeds.

\section{Conclusions}

Nanotechnology has the potential to revolutionize the diagnostics, discovery of new drugs, drug delivery, vaccine development and tissue engineering. It can be efficiently utilized to improve the animal production through breeding, reproduction and new alternatives for animal nutrition. The nutritive value, product quality and shelf life of the animal products can also be enhanced through the use of this technology. Many of the products are either under development or in experimental stages. The results in experimental animals suggest that these products can be extremely useful for application in domestic animals. Nanomaterials create amazing efficiencies, but at the same time these particles have the potential to affect vital organs of the body. ${ }^{100}$ Nanoparticles have the potential to cause hazardous effects not only to humans or animals, but they also have the potential to cause deleterious effects on the environment. Nanomaterials like carbon nanofibres have been reported to contribute towards global warming and ozone layer depletion. ${ }^{101}$ There are still many challenges to be faced in terms of the potential toxic effects of nanoparticles. There is, therefore, also a need to look into the safety and other social issues that are likely to arise from these applications.

\section{References}

1. Gordon N, Sagman U. Nanomedicine Taxonomy; briefing paper. Can Nanobus All 2003;1-28.

2. Lee KB, Lim JH, Mirkin CA. Protein nanostructures formed via direct-write dip-pen nanolithography. J Am Chem Soc 2003; 125:5588-9.

3. Nam JM, Thaxton CS, Mirkin CA. Nanoparticle-based bio-bar codes for the ultrasensitive detection of proteins. Science 2003;301:1884-6.

4. Fair RB, Khlystov A, Tailor TD, et al. Chemical and Biological Applications of Digital-Microfluidic Devices. Design Test Comp 2007;24:10-24

5. Kovarik ML, Jacobson SC. Nanofluidics in Lab-on-a-Chip. Devices Anal Chem 2009; 81:7133-40.

6. Campbell G. Nanotechnology and its implications for the health of the E.U citizen: Diagnostics, drug discovery and drug delivery. Available from: http://www.nano. org.uk/nanomednet/images/stories/Report s/diagnostics

7. Tran TD, Caruthers SD, Hughes M, et al. Clinical applications of perfluorocarbon nanoparticles for molecular imaging and targeted therapeutics. Int $\mathrm{J}$ Nanomed 2007;2:515-26.

8. Peng XH, Qian X, Mao H, et al. Targeted magnetic iron oxide nanoparticles for tumor imaging and therapy. Int J Nanomed 2008;3:311-21.

9. Feneque J. Brief Introduction to the Veterinary Applications of Nanotechnology. 2003. Available from: www.nanotechnow.com/Jose-Feneque/Veterinary-Applications-Nanotechnology.htm

10. Longmire M, Choyke PL, Kobayashi H. Clearance properties of nano-sized particles and molecules as imaging agents: considerations and caveats. Nanomedicine 2008;3:703-17.

11. Ernest H, Shetty R. Impact of Nanotechnology on Biomedical Sciences: Review of Current Concepts on Convergence of Nanotechnology with Biology. Online J Nanotechnol 2005. Available from: http://www.azonano.com/article. aspx?ArticleID=1242

12. Scott NR. Nanoscience in Veterinary Medicine. Vet Res Commun 2007;31:S13944.

13. Freitas RA. Current status of nanomedicine and medical nanorobotics. J Comput Theor Nanosci 2005;2:1-25.

14. Israel B, Abbott N, Murphy C, Hollister K, Soltaninassab S, Hansmann D, Acharya BR (inventors) Platypus Technologies LLC assignee. Liquid crystal based analyte detection. US patent n 20100009344. 2010.

15. Luo D. Sustained release of pST from biocompatible and biodegradable nano/microspheres. 2003. Available from: http://www. reeis.usda.gov/web/crisprojectpages/ 197897.html

16. Desai TA, Chu WH, Tu JK, et al. Micro-fabricated immunoisolating biocapsules. Biotechnol Bioeng. 1998;57:118-20.
17. Leoni L, Desai TA. Micromachined biocapsules for cell-based sensing and delivery. Adv Drug Deliv Rev 2004;56:211-29.

18. Harvey J. Nanotechnology: A New Revolution in Primary Care \& Diagnostics. 2011. Available from: http://www.medlinkuk.org/Site/documents/Nano2011/HarveyJ. pdf

19. Prajapati B, Patel M, Jayvadan K, et al. The upcoming era of nanomedicine: a briefing: nanomedicine. Drug Deliv Technol 2008;8:46.

20. Espuelas MS, Legrand P, Campanero MA, et al. Polymeric carriers for amphotericin B: in vitro activity, toxicity and therapeutic efficacy against systemic candidiasis in neutropenic mice. J Antimicrob Chemother 2003;52:419-27.

21. van Etten EW, ten Kate MT, Stearne LE, Bakker-Woudenberg IA. Amphotericin B liposomes with prolonged circulation in blood: in vitro antifungal activity, toxicity, and efficacy in systemic candidiasis in leukopenic mice. Antimicrob Agents Chemother 1995;39:1954-8.

22. Nahar M, Jain NK. Preparation, characterization and evaluation of targeting potential of amphotericin B-loaded engineered PLGA nanoparticles. Pharm Res 2009;26: 2588-98.

23. Gaspar R, Preat V, Opperdoes FR, Rolland M. Macrophage activation by polymeric nanoparticles of polyalkylcyanoacrylates: activity against intracellular Leishmania donovani associated with hydrogen peroxide production. Pharm Res 1992;9:782-7.

24. Tyagi R, Lala S, Verma AK, et al. Targeted delivery of arjunglucoside I using surface hydrophilic and hydrophobic nanocarriers to combat experimental leishmaniasis. J Drug Target 2005;13:161-71.

25. Fattal E, Youssef M, Couvreur P, Andremont A. Treatment of experimental salmonellosis in mice with ampicillinbound nanoparticles. Antimicrob Agents Chemother 1989;33:1540-3.

26. Legrand P, Barratt G, Mosqueira V, et al. Polymeric nanocapsules as drug delivery systems: a review. Sci Tech Pharm 1999; 9:411-8.

27. Seleem MN, Jain N, Pothayee N, et al. Targeting Brucella melitensis with polymeric nanoparticles containing streptomycin and doxycycline. FEMS Microbiol Lett 2009;294: 24-31.

28. Pandey R, Zahoor A, Sharma S, Khuller GK. Nanoparticle encapsulated antitubercular drugs as a potential oral drug delivery system against murine tuberculosis. Tuberculosis 2003;83:373-8.

29. Sharma A, Pandey R, Sharma S, Khuller GK. Chemotherapeutic efficacy of poly (dllactide-co-glycolide) nanoparticle encapsulated antitubercular drugs at sub-thera- 
peutic dose against experimental tuberculosis. Int J Antimicrob Agents 2004;24:599604.

30. Morilla MJ, Montanari J, Frank F, et al. Etanidazole in $\mathrm{pH}$-sensitive liposomes: Design, characterization and in vitro/in vivo anti-Trypanosoma cruzi activity. J Control Release 2005;1003:3599-607.

31. Chu P, Sadullah S. The current role of amphotericin B lipid complex in managing systemic fungal infections. Curr Med Res Opin 2009;25:3011-20.

32. Scott NR. Nanotechnology and Animal Health. Rev Sci Tech Off Int Epiz 2005; 24:425-32.

33. Suzuki Y, Tanihara M, Nishimura Y, et al. A new drug delivery system with controlled release of antibiotic only in the presence of infection. J Biomed Mater Res 1998; 42:112-6.

34. Tanihara M, Suzuki Y, Nishimura Y, et al. A novel microbial infection-responsive drug release system. J Pharm Sci 1999;88:510-4.

35. Soppimath KS, Aminabhavi TM, Dave AM, et al. Stimulus-responsive "smart" hydrogels as novel drug delivery systems. Drug Dev Ind Pharm 2002;28:957-74.

36. Brahim S, Narinesingh D, Guiseppi-Elie. A Bio-smart hydrogels: co-joined molecular recognition and signal transduction in biosensor fabrication and drug delivery. Biosens Bioelectron 2002;17:973-81.

37. Landers JJ, Cao Z, Lee I, , et al. Prevention of influenza pneumonitis by sialic acidconjugated dendritic polymers. J Infect Dis 2002;186:1222-30.

38. West JL, Halas NJ. Applications of nanotechnology to biotechnology. Curr Opin Biotechnol 2000;11:215-7.

39. McCarthy JJ, Hilfiker R. The use of singlenucleotide polymorphism maps in pharmacogenomics. Nature Biotechnol 2000; 18:505-8.

40. Aneesh TP, Sonal Sekhar M, Asha Jose, et al. Pharmacogenomics: The right drug to right person. J Clin Med Res 2009;1:191-4.

41. Winegarden N, Woodgett J. Microarrays and Drug Discovery - An Update. 2006 Available from: http://www.touchbriefings.com/pdf/1620/Winegarden\%5B1\%5D.pd $\mathrm{f}$

42. Ricca E, Cutting SM. Emerging Applications of Bacterial Spores in Nanobiotechnology. J Nanobiotechnol 2003;1:6.

43. Prasanna, BM. Nanotech in Agriculture. In: R Gupta, VK Gupta, LM Bhar, VK Bhatia VK (eds.). Advances in data analytical techniques. New Delhi: Indian Agricultural Statistics Research Institute (ICAR); 2007. pp. 111-118.

44. Black M, Trent A, Tirrell M, Olive C. Advances in the design and delivery of peptide subunit vaccines with a focus on Toll-like receptor agonists. Expert Rev
Vaccines 2010;9:157-73.

45. Pavelic K, Hadzija M, Bedrica L, et al. Natural zeolite clinoptilolite: new adjuvant in anticancer therapy. $\mathrm{J}$ Mol Med 2001;78:708-20.

46. Walsh MC, Banas JA, Mudzinski SP, et al. A two-component modular approach for enhancing T-cell activation utilizing a unique anti-FcgammaRI-streptavidin construct and microspheres coated with biotinylated-antigen. Biomed Eng 2003;20: 21-33.

47. Venter PA, Dirksen A, Thomas D, et al. Multivalent display of proteins on viral nanoparticles using molecular recognition and chemical ligation strategies. Biomacromolecules 2011;12:2293-301.

48. Ulrich R, Nassal M, Meisel H, Krüger DH. Core particles of hepatitis $\mathrm{B}$ virus as carrier for foreign epitopes. Adv Virus Res 1998;50:141-82.

49. Plummer EM, Manchester M. Viral nanoparticles and virus-like particles: platforms for contemporary vaccine design. Adv Rev 2011;3:174-96.

50. Scheerlinck JY, Gloster S, Gamvrellis A, et al. Systemic immune responses in sheep, induced by a novel nano-bead adjuvant. Vaccine 2006;24:1124-31.

51. Nandedkar TD. Nanovaccines: recent developments in vaccination. $\mathrm{J}$ Biosci 2009;34:95-1003.

52. Slutter B, Hagenaars N, Jiskoot W. Rational design of nasal vaccines. J Drug Target 2008;16:1-17.

53. Myc A, Kukowska-Latallo JF, Bielinska AU, et al. Development of immune response that protects mice from viral pneumonitis after a single intranasal immunization with influenza A virus and nanoemulsion. Vaccine 2003;21:3801-14.

54. Bhavsar MD, Aniji MM. Polymeric nanoand microparticle technologies for oral gene delivery. Expert Opin Drug Deliv 2007;4:197-213.

55. Wambura PN. Formulation of novel nanoencapsulated Newcastle disease vaccine tablets for vaccination of village chickens. Trop Anim Health Prod 2011;43:165-9.

56. Bielinska AU, Janczak KW, Landers JJ, et al. Mucosal immunization with a novel nanoemulsion-based recombinant anthrax protective antigen vaccine protects against Bacillus anthracis spore challenge. Infect Immun 2007;75:4020-9.

57. Hamouda T, Sutcliffe JA, Ciotti S, Baker JR. Intranasal Immunization of Ferrets with Commercial Trivalent Influenza Vaccines Formulated in a NanoemulsionBased Adjuvant. Clin Vaccine Immunol 2011;18:1167-75.

58. Bahreini MAD, Shokri J, Samiei A, et al. Nanovaccine for leishmaniasis: preparation of chitosan nanoparticles containing
Leishmania superoxide dismutase and evaluation of its immunogenicity in BALB/c mice. Int J Nanomed 2011;6:83542.

59. Okamoto S, Matsuura M, Akagi T, et al. Poly ( $\gamma$-glutamic acid) nano-particles combined with mucosal influenza virus hemagglutinin vaccine protects against influenza virus infection in mice. Vaccine 2009;27:5896-905.

60. Kim SY, Doh HJ, Jang MH, et al. Oral immunization with Helicobacter pyloriloaded poly (dl-lactideco-glycolide) nanoparticles. Helicobacter 1999;4:33-9.

61. Jung T, Kamm W, Breitenbach A, et al. Tetanus toxoid loaded nanoparticles from sulfobutylated poly(vinylalcohol)-graftpoly-(lactide-co-glycolide): evaluation of antibody response after oral and nasal application in mice. Pharm Res 2001;18: 352-60.

62. Vila A, Sanchez A, Evora C, et al. PEG-PLA nanoparticles as carriers for nasal vaccine delivery. J Aerosol Med 2004;17;174-85.

63. Conway MA, Madrigal-Estebas L, McClean $\mathrm{S}$, et al. Protection against Bordetella pertussis infection following parenteral or oral immunization with antigens entrapped in biodegradable particles: effect of formulation and route of immunization on induction of Th1 and Th2 cells. Vaccine 2001;19:1940-50.

64. Ochoa-Reparaz J, Sesma B, Alvarez M, et al. Humoral immune response in hens naturally infected with Salmonella Enteritidis against outer membrane proteins and other superficial structural antigens. Vet Res 2004;5:291-8.

65. Chen SC, Jones DH, Fynan EF, et al. Protective immunity induced by oral immunization with a rotavirus DNA vaccine encapsulated in microparticles. J Virol 1998;72:5757-61.

66. Illum L, Jabbal-Gill I, Hinchcliffe M, et al. Chitosan as a novel nasal delivery system for vaccines. Adv Drug Deliv Rev 2001; 51:81-96.

67. Florindo HF, Pandit S, Lacerda L, et al. The enhancement of the immune response against $S$. equi antigens through the intranasal administration of poly-epsiloncaprolactone-based nanoparticles. Biomaterials 2009;30:879-91.

68. Xu J, Dai W, Wang Z, et al. Intranasal vaccination with chitosan-DNA nanoparticles expressing pneumococcal surface antigen a protects mice against nasopharyngeal colonization by Streptococcus pneumoniae. Clin Vaccine Immunol 2011;18:75-81.

69. Read RC, Naylor SC, Potter CW, et al. Effective nasal influenza vaccine delivery using chitosan. Vaccine 2005;23:4367-74.

70. Chen YS, Hung YC, Lin WH, Huang GS. Assessment of gold nanoparticles as a 
size-dependent vaccine carrier for enhancing the antibody response against synthetic foot-and-mouth disease virus peptide. Nanotechnology 2010;21:195101.

71. Greenwood DLV, Dynon K, Kalkanidis M, et al. Vaccine against foot-and-mouth disease virus using peptides conjugated to nano-beads. Vaccine 2008;26:2706-13.

72. He Q, Mitchell A, Morcol T, Bell SJD. Calcium Phosphate Nanoparticles Induce Mucosal Immunity and Protection against Herpes Simplex Virus Type 2. Clin Diagn Lab Immunol 2002;9:1021-4.

73. Fernando GJP, Chen X, Prow TW, et al. Potent Immunity to Low Doses of Influenza Vaccine by Probabilistic Guided Micro-Targeted Skin Delivery in a Mouse Model. PLoS ONE 2010;5:e10266.

74. Tomlinson E, Rolland AP. Controllable gene therapy pharmaceutics of non-viral gene deliv ery systems. J Control Release 1996;1:357-72.

75. Katragadda CS, Choudhury PK, Murthy PN. Nanoparticles as Non-Viral Gene Delivery Vectors. Indian J Pharm Educ Res 2010;44:109-20.

76. Roy K, Mao HQ, Leong KW. DNA-chitosan nanospheres: Transfection efficiency and cellular uptake. Proc Int Sym Control Rel Bioact Mater 1997;24:673-4.

77. Murata J, Ohya Y, Ouchi T. Design of quaternary chitosan conjugate having antennary galactose residues as a gene delivery tool. Carbohyd Polym 1998;32:105-9.

78. McKnight TE, Melechko AV, Griffin GD, et al. Intracellular integration of synthetic nanostructures with viable cells for controlled biochemical manipulation. Nanotechnology 2003;14:551-6.

79. Luo D, Han E, Belcheva N, Saltzman WM. A self-assembled, modular DNA delivery system mediated by silica nanoparticles. J Control Release 2004;95:333-41.

80. Paunesku T, Rajh T, Wiederrecht G, et al. Biology of TiO2-oligonucleotide nanocomposites. Nature Mater 2003;2:343-6.

81. Salem AK, Searson PC, Leong KW.
Multifunctional nanorods for gene delivery. Nature Mater 2003;2:668-71.

82. Hamad-Schifferli K, Schwartz JJ, Santos AT, et al. (Remote electronic control of DNA hybridization through inductive coupling to an attached metal nanocrystal antenna. Nature 2002;415:152-5.

83. Du C, Cui FZ, Feng QL, et al. Tissue Response to Nano-Hydroxyapatite/Collagen Composite Implants in Marrow Cavity. J Biomed Mater Res 1998;42:540-8.

84. Wang X, Li Y, Wei J, de Groot K. Development of Biomimetic Nanohydroxyapatite/Poly (Hexamethylene Adipamide) Composites. Biomaterials 2002;23: 4787-91.

85. 0'Connell MJ, Bachilo SM, Huffaman CB, et al. Band gap fluorescence from individual single walled carbon nanotubes. Science 2002;297:593-6.

86. Patil SS, Kore1 KB, Kumar P. Nano-technology and its applications in Veterinary and Animal Science. Vet World 2009;2:4757.

87. Jelinek CF, Pohland AE, Wood GE. Worldwide occurrence of mycotoxins in foods and feeds - an update. J Assoc Anal Chem 1989;72:223-30.

88. Moghaddam SHH, Jebali A, Daliri K. The use of $\mathrm{MgO}-\mathrm{SiO} 2$ nanocomposite for adsorption of aflatoxin in wheat flour samples. 2010. Available from: http://www. nanocon.cz/data/nanocon2010/sbornik/list s/papers/524.pdf

89. Shi YH, Xu ZR, Feng JL, Wng CZ. Efficacy of modified montmorillonite nanocomposite to reduce the toxicity of aflatoxin in broiler chicks. Anim Feed Sci Technol 2006;129:138-48.

90. Keener KM, Bashor MP, Curtis PA, et al. Comprehensive review of Campylobacter and poultry processing. Compr Rev Food Sci F 2006;3:105-16.

91. Franklin JL, Sheldon BW, Grimes JL, Wineland MJ. Use of biofunctionalized nanoparticles to bind Campylobacter jejuni in poultry. Poult Sci 2003;82:S31.
92. Latour RA, Stutzenberger FJ, Sun YP, et al. Adhesion-specific nanoparticles for removal of Campylobacter jejuni from poultry. 2003. Available from: http://www. reeis.usda.gov/web/crisprojectpages/ 186571.html

93. Fondevila M, Herrer R, Casallas MC, et al. Silver nanoparticles as a potential antimicrobial additive for weaned pigs. Anim Feed Sci Tech 2009;150:259-69.

94. Tong G, Yu-long, MA, Zi-rong, XU. Effects of $\mathrm{Cu}$ (II)-exchanged montmorillonite nanoparticles on growth performance, digestive function and mucosal disaccharase activities of weaned pigs. Chinese $\mathrm{J}$ Anim Sci 2007;21.Abstr.

95. Chaudhry Q, Castle L. Food applications of nanotechnologies: An overview of opportunities and challenges for developing countries. Trends Food Sci Technol 2011;22: 595-603.

96. Yang H, Qu L, Wimbrow AN, et al. Rapid detection of Listeria monocytogenes by nanoparticle-based immunomagnetic separation and real-time PCR. Int J Food Microbiol 2007;118:132-8.

97. Zhang D, Carr DJ, Alocilja EC. Fluorescent bio-barcode DNA assay for the detection of Salmonella enterica serovar Enteritidis. Biosens Bioelectron 2009;24:1377-81.

98. Kuzma J. Nanotechnology in animal production-Upstream assessment of applications. Livest Sci 2010;130:14-24.

99. Li Li, Baoxin Li, Di Cheng, Lihui Mao. Visual detection of melamine in raw milk using gold nanoparticles as colorimetric probe. Food Chem 2010;122:895-900.

100.Medina C, Santos-Martinez MJ, Radomski A, et al. Nanoparticles: pharmacological and toxicological significance. $\mathrm{Br} \mathrm{J}$ Pharmacol 2007;150:552-8.

101.Khanna V, Bakshi BR, Lee LJ. Carbon Nanofiber Production: Life Cycle Energy Consumption and Environmental Impact. J Ind Ecol 2008;12:394-410. 